\title{
The Development of Student Worksheet Based on Project-Based Learning Model to Improve Student Learning Outcomes of Five-Grade in Elementary School
}

\author{
Muhammad Nur Rohim $^{1 *} \quad$ Lilik Sabdaningtyas $^{2} \quad$ Arwin Subakti $^{3} \quad$ Rochmiyati $^{4}$ \\ Faculty of Teacher Training and Education, University of Lampung \\ St. Soemantri Brojonegoro No.1 Gedung Meneng Bandar Lampung 35145
}

\begin{abstract}
The purpose of this research and development is to develop and describe the feasibility and effectiveness of developing student worksheets based on project-based learning to improve learning outcomes of fifth-grade in Elementary School. This type of research is research and development refers to Borg and Gall theory. The population of this study was fifth-grade students in Primary Schools in Jati Agung District, and the sample was determined by a random sampling of 22 students of Public Elementary School in Margakaya. Data were collected through observation sheets, questionnaires, and test questions. The instrument used in this study was a questionnaire of the validity and effectiveness of the product on the Student Worksheet based on Project Based Learning and student test results. Data analysis uses qualitative and quantitative analysis techniques. The results showed that the Thematic Student Worksheets based on Project Based Learning fulfill valid and effective criteria with a gain value of 0.41 . Improving the thematic learning outcomes of the analysis of the Minimum Mastery Criteria ( $\geq 66$ ) was $95.83 \%$ in the fifth-grade student of Elementary School.
\end{abstract}

Keywords: Project-Based Learning, Student Worksheets, Thematic.

DOI: $10.7176 / \mathrm{JEP} / 11-17-09$

Publication date:June 30th 2020

\section{INTRODUCTION}

Education is something that must be done by every human being, the quality of the human self will be better with the presence of education, both education in the family environment and education outside the family such as at school. Education plays an important role in human life, with education, people will be trained to face existing problems.

Indonesia currently refers to the 2013curriculum. The curriculum explains that quality education involves students to be active in learning, in order to achieve quality in learning activities need to use the principles of (1) learner-centered learning, (2) developing student creativity, (3) creating enjoyable learning conditions, (4) having values, ethics, aesthetics, logic and kinesthetic, (5) applying various learning strategies and methods (Hosnan, M, 2014: 27). Learning is a process of changing behavior in students through practice and experience. The results of learning can be seen from the competence of students.

According to Watson (2002: 208) defines learning outcomes as something students get so that students can do it now, meanwhile previously students could not do it. This means that there are results obtained by students after going through the learning process, learning outcomes are not only one but diverse. Learning outcomes will be good if the planning in managing learning is good, according to Sutama (2012: 43) states that aspects of learning management include planning, organizing, implementing, and evaluating learning outcomes.

This opinion explains that the factors that influence learning outcomes are external and internal factors, while the opinion of Usman is more inclined to external factors, that are educators. Educators in learning must have eight basic skills including asking questions, giving reinforcement, making variations, explaining, opening and closing lessons, guiding small group discussions, managing classes, and teaching individuals. This means that the teacher's role is very influential in student learning outcomes.

In reality, many educators do not pay attention to the use of learning methods in every learning, learning is usually only delivered conventionally, where the teacher plays an active role, while students tend to be passive. The passive attitude of students can reduce their involvement in the learning process that can result in a decrease in students' interest in participating in the learning process. One of the efforts that can be done by the teacher is to choose a learning model that can make students active in learning, provide learning experiences, present concepts from various learning materials, and in accordance with the characteristics of students and provide relevant media and learning teaching materials. Teaching materials can serve as a direction for the learning process to be carried out. Considering the importance of teaching materials in teaching and learning activities, it is necessary to pay attention to the quality both in terms of content, language, graphic elements, illustrations, and methods of development.

The student activity sheet is one of the teaching materials in which there are instructions, materials, and learning steps that serve as a guide for students in carrying out the learning process. Through Student Worksheets, 
students' activities and creativity in learning can be improved, the delivery of subject matter can be facilitated by using Student Worksheets.

The results of observations of learning activities conducted on February 4, 2019, in the Gajah Mada group that consists of five schools. It is found that the learning process was still not able to make a pleasant learning atmosphere in the learning environment of learners, learning tends to be active and monotonous educators. Facts in the field when observing include (a.) The teacher has not used the Student Worksheet that uses 2013curriculum. (B.) The Student Worksheet used already contains material and questions but the activities and learning steps that are on the Worksheet The Learned Students are not clear and appear when using the Student Worksheets, the students look confused or lack understanding of the work orders on the Student Worksheets. (c. students who follow the learning look passive, this can be seen in the question and answer session and when given the opportunity to argue students are not actively asking questions and are still shy (d.) students have not been conditioned in doing group or individual learning, this is seen when in small groups, students in the division of tasks have not been well trained in problem-solving (e.) teachers use textbook media that only come from school libraries.

Widjajanti (2008: 1) said the Participant Worksheet is one of the learning resources that can be developed by educators as facilitators in learning activities. Student Worksheets that are arranged can be designed and developed according to the conditions and situations of learning activities that will be encountered. Students' Worksheets need to be developed and made in a structured and attractive manner. The use of Student Worksheets in learning is useful for processing material that is studied both individually and in groups. Student Worksheets are a form of teacher effort in guiding students in a structured manner, where activities are made as attractive as possible to attract students' interest in learning.

In its capacity as an educator, teachers are expected to provide an attractive alternative learning model and can support the growth of learning activities that are centered on students (Ministry of Education and Culture, 2008: 18). One learning model that can meet these demands is a project-based learning model. Based on these characteristics according to McDonell (in Abidin, 2014: 169) explains that project-based learning is a learning model that is developed based on the level of student development by focusing on student learning activities so as to enable them to move according to their skills, comfort, and learning interests.

\section{RESEARCH METHOD}

This type of research using research and development refers to Borg \& Gall's theory (1983: 772) about Research-Based-Development according to research objectives that are research procedures with the aim to develop and validate the educational products developed. Sugiyono (2013: 407) explains Research \& Development is a research method used to produce certain products, and test the effectiveness of these products. The type of development of the Student Worksheet used in this study is to adapt the development procedures developed by Borg and Gall.

The research population is the fifth-grade students in elementary school in Jati Agung which have implemented the 2013curriculum, and the sample is determined by random sampling of 22 students in Public Elementary School of Margakaya, Jati Agung, South Lampung Regency. Considering that Public Elementary School Margakaya is a model school for implementing the 2013curriculum.

Tool for collecting data on the Development of Workbench Educators based on Problem Based Learning uses a questionnaire, which is the validation of curriculum and learning experts covering aspects of the material, language, and media. Learning outcomes are obtained from the results of the pretest and posttest learning using the Problem Based Learning Participant Worksheet, using valid and reliable test instruments, and considering the level of difficulty and different questions. Data analysis technique to see the effectiveness between the use of Problem Based Learning Worksheet for Learning Based on learning is done by analyzing the average value of normalized gain with the n-Gain formula based on the results of the pre-test and post-test. Hake (in Sundayana, 2015: 149) revealed that to know the effectiveness of learning in conceptual understanding.

\section{RESEARCH RESULTS AND DISCUSSION}

\subsection{Research Results Development of Student Worksheets based on Problem Based Learning to improve learning outcomes}

The results of the research and development of Student Worksheets based on Problem Based Learning to improve learning outcomes of fourth-grade students, obtained the following results.

\subsubsection{Research and Information Collection}

This stage aims to review the issues to be studied. According to Sukmadinata (2011: 44), a preliminary study is the initial stage of preparation by collecting data about existing conditions as a comparison material for products to be developed. In this case, the researchers conducted an analysis of student needs by observing. The results of observations include: 1) Educators have not used the Student Worksheet based on Problem Based Learning with the 2013curriculum. 2) The steps or instructional activities on the Student Participant Worksheet are unclear. 3) 
Educators who follow learning look passive. 4) Students have not been trained in a group or individual learning. 5) Students have not been led to be able to create a work or product after a series of learning.

\subsubsection{Planning (Planning)}

Planning is done by analyzing the results of information gathering. The product to be developed is a learning device consisting of a syllabus, Learning Implementation Plan, Student Worksheets, and assessment instruments. Furthermore, the authors systematically compile the basic competencies, indicators, and learning objectives developed in this study.

\subsubsection{Initial Product Format Development}

The steps in developing a thematic-integrative learning tool based on Problem Based Learning are as follows.

\section{a. Preparing Student Worksheet products based on Problem Based Learning}

The Problem Based Learning Worksheet for Students that is developed is a learning tool in the fifth grade. The following are the initial product prototypes of the learning tools compiled. Syllabus, Learning Implementation Plan, and student worksheets (Cover, Preface, Table of Contents, Mapping of Basic Competencies, Instructions for Use, Description of Material and Activities, Evaluation, Bibliography) and Test Instruments.

\section{b. Product Validation and Product Revision}

Product validation is carried out by experts to assess the validity of the product. Next is the learning expert, which is material, language, and media experts assess does the Student Worksheets based on Problem Based Learning rationally will be valid and effective when used to improve student learning outcomes. The first is an expert learning assessment done on Student Worksheets product based on Problem Based that consisting of material experts and media experts. The expert is a Lecturer from Lampung University. Based on the learning expert test, there are some things that need to be improved, that are (1) Improving in cover design, (2) Core Competency needs to be added, and (3) rice plant flow scheme in the material description needs to be clarified. Then test the evaluation experts, test instruments to measure student learning outcomes before and after using teaching materials in the form of Student Worksheets based on Problem Based Learning, validated first with trials on fifth-grade students at Public Elementary School 2 Margakaya. From 35 questions tested there were 33 valid items).

\subsubsection{Preliminary Field Testing}

\section{a. Product trials are limited to small groups}

This test was conducted in the fifth grade of Public Elementary School 2 Marga Agung. The assessment by small groups was carried out by 9 people consisting of 3 people from the group with high initial ability, 3 people from the group with moderate ability, and 3 people from the low group. Empirical instrument test results about the pre-test for limited product trials were conducted in the fifth grade of Public Elementary School 2 Marga Agung as many as 9 students. The pre-test questions that were tested for product trials were limited to multiple-choice questions with 35 items. A total of 33 questions were valid and 2 questions were invalid. The reliability of the questions is 0.74 . Invalid questions, that are questions number 7 and 17. The questions have valid coefficients of 0.08 (very low) and 0.06 (very low).

The questions that were tested for the post-test limited product trial were conducted on the fifth grade in Public Elementary School 2 Marga Agung as many as 9 students. In multiple-choice questions as many as 35 items. As many as of 32 questions are valid and 3 questions are invalid. The reliability of the questions is 0.83 . Invalid questions, that are questions number 9, 19, and 26. These questions have valid coefficient values of 0.16 (very low), 0.31 (low) and 0.16 (very low). Based on the results of the instrument test, the questions that are not used are questions number 9, 19, and 26. The questions are not used and are not corrected because there are still questions that represent indicators of questions that are not used.

\section{b. Main field trials}

Empirical test results of the test instruments empirically for an expanded usage test were carried out in fifth grade of Public Elementary School in Margakarya with a total of 22 students. The pre-test questions that were tested for the trial use were expanded on multiple-choice questions by 32 items. A total of 31 questions were valid and 1 question was invalid. The reliability of the questions is 0.72 . The invalid question, which is question number 7. The problem has a valid coefficient of 0.09 (very low). Based on the results of the instrument trial, the questions that are not used are question number 7. The questions are not used and are not corrected because there are still questions that represent indicators of questions that are not used.

Post-test questions on expanded use trials were conducted at Margakarya State Primary School in fifth grade with a total of 19 students. Post-test questions on multiple-choice questions that were tested for trial use were expanded by 32 items. A total of 30 questions are valid and 2 questions are invalid. The reliability of the questions is 0.73 . Invalid questions are questions number 15 and 19. These questions have valid coefficients of 0.14 (very low) and 0.18 (very low). Based on the test results of the instrument, the questions that are not used are questions number 15 and 19. The questions are not used and are not corrected because there are still questions that represent indicators of the questions that are not used. 


\section{c. N-Gain Test}

To find out the effectiveness of Project Based Learning Worksheets, students can be tested with an average calculation of the nominal gain. Improvements that occur before and after learning are calculated by the formula $\mathrm{g}$ factor (N-gains),

$$
\mathrm{N} \text {-gains }=\frac{\text { Final test score }(\text { posttest })-\text { preliminary test score }(\text { Pretest })}{\text { Maximum score }- \text { initial test score }}
$$

Table 1. Calculation of Cognitive Learning Outcomes Pre-Test and Post-test based on Project-Based Learning

\begin{tabular}{|l|l|l|l|}
\hline Information & Pre-Test & Post-Test & $\begin{array}{l}\text { Gain } \\
\text { (Post-Test - Pre-Test) }\end{array}$ \\
\hline Amount of Values & 1536.67 & 1886.67 & \multirow{2}{*}{350.00} \\
\cline { 1 - 2 } Total students & 22 & 22 & \\
\cline { 1 - 2 } Average & 65.83 & 77.92 & \\
\cline { 1 - 2 } Md & 24.53 & & \\
\hline
\end{tabular}

N-gains $=\frac{1886,67-1536,67}{2400-1536,67}=0.41$, with a moderate category, based on the results of the Minimal completeness criteria analysis $(\geq 66)$ is $95.83 \%$, then the Student Worksheets based on Project Based Learning is effective to use in the fourth grade of Public Elementary School in Margakarya.

\section{d. T-test}

The t-test is a clue to find out whether or not there is an average difference between two unrelated sample groups. The data used is usually an interval or ratio scale, with the following hypotheses:

Ho $=$ There is no difference in learning outcomes between students in the experimental class who use Thematic Student Worksheets based on Project Based Learning and students in control classes who do not use Thematic Student Worksheets based on Project Based Learning.

$\mathrm{Ha}=$ There are differences in learning outcomes between students in the experimental class who use Thematic Student Worksheets based on Project Based Learning and students in control classes who do not use Thematic Student Worksheets based on Project Based Learning.

Obtained data of $t$ count $=106,482 ; \mathrm{t}$ table $=1.9966$. Accordingly, that tcount $>\mathrm{t}$ table, then Ho in Decline and Ha accepted $=>$ Significant. The conclusion is there are differences in learning outcomes between students in the experimental class who use Thematic Student Worksheets based on Project Based Learning with students in control class who do not use Thematic Student Worksheets based on Project Based Learning and learning using Thematic Student Worksheets based on Project Based Learning better than learning that does not use Thematic Student Worksheets based on Project Based Learning.

\subsubsection{Main Product Revision}

It is showed that there is a significant increase in learning outcomes, so the product does not need to be revised, and is suitable for use.

\subsection{Discussion}

\subsubsection{Development of Student Worksheets based on Project-Based Learning}

The first preliminary study consists of a literature study and field study. This step is done by analyzing the material and analyzing the Content Standards which include Competency Standards and Basic Competencies to design learning tools that are a reference in developing Thematic Student Worksheets with themes. In addition, it also looks for literature related to the development of Project Based Learning Worksheet Learners. Second, the field study is an activity carried out in the Elementary School of Jati Agung, South Lampung. The instrument used in this field study was the interview sheet. Interviews were conducted with teachers and students in fifth grade. Then identify the Student Worksheet related material. As with library studies, what is defined is the strengths and weaknesses of the Student Worksheet.

After conducting a preliminary study, the product development activities include the preparation of a Thematic Student worksheet based on Project Based Learning. After all of them are arranged, the next step is to arrange the material. In this material, the approach will be used with Project-Based Learning. Reference in the planning and development of Thematic Student Worksheets based on Project Based Learning is a result of the needs analysis that has been done. The preparation of this Thematic Student Worksheets based on Project Based Learning is based on guidelines for the preparation of the Student Worksheet.

Then do product validation and product revision. After completing the preparation of Thematic Student Worksheets based on Project Based Learning, then the Student Worksheet is validated by an expert person. Assessment by design experts includes the suitability of the Student Worksheet with didactic requirements, construction requirements, and technical requirements. Product evaluation and validation are carried out by expert lecturers at the postgraduate Lampung University. Validation activity is a process of evaluating conformity to content standards, basic competencies and indicators to find out if the Student Worksheets that 
have been prepared have met the category of good Student Worksheets, as well as to find out if the Student Worksheets that are prepared are in accordance with school needs based on the results of preliminary studies.

Furthermore, try out limited products (small groups). Limited product trials to determine the feasibility of the Student Worksheet, but also aim to evaluate the completeness of the material, the truth of the material, systematic material, and various matters related to the material such as examples and phenomena as well as the development of practice questions. Also to evaluate product design, product quality, attractiveness, and legibility. The Student Worksheet is tested on fifth-grade students consisting of 6 students using a student assessment questionnaire.

The Development of Student-Based Worksheets based on Project Based Learning is one of the results of innovations developed by researchers very suitable to be used as a reference and companion for the development of subject matter contained in the 2013 curriculum student books because these Student Worksheets are designed and developed referring to books students and teachers with a scientific learning approach pattern and integrated thematic learning models.

\subsubsection{The Effectiveness of Thematic Students Worksheets Based on Project-Based Learning}

The product produced in this research development is a Student Worksheet in the form of a Thematic Student Worksheet. This thematic Student Worksheet uses a Project-Based Learning approach with the theme of my goals consisting of learning 1 through learning 6. This thematic Student Worksheet contains material and exercises and is complemented by pictures as a media for observing material developed based on standards contents of the 2013curriculum which are core competencies and basic competencies developed in the formulation of indicators and implemented in objectives. The first step provides pretest questions to see the initial abilities. Then do the learning by using Thematic Student Worksheet based on Project Based Learning. Finally, giving posttest questions to see the competencies of students.

Based on the activities mentioned above, the effectiveness of learning is measured through student learning outcomes, by looking at the level of learning outcomes obtained before students use Thematic Student Worksheet based on Project Based Learning and after using Thematic Student Worksheet based on Project Based Learning. Learning by using Thematic Student Worksheet based on Project Based Learning is said to be effective if the N-Gain value of students is higher in students whose learning uses Thematic Student Worksheet based on Project Based Learning compared to students whose learning does not use Thematic Student Worksheet based on Project Based Learning.

The results showed that the Thematic Student Worksheet based on Project Based Learning that was developed included effective criteria, this can be seen from the difference in the acquisition of learning outcomes in the experimental class that is the value of N-Gain 0.451418 and in the control class that is the N-Gain value 0.304851 .

The thematic approach included in the learning media in the form of Student Worksheets is very effective to use. (Dirman and Cicih Juarsih, 2014: 106) say this thematic approach is believed to be one of the effective learning models because it is able to accommodate and touch in an integrated emotional, physical, and academic dimension in the classroom or school environment.

Field test results in the experimental class and the control class in the research development of the Thematic Student Worksheet based on Project Based Learning obtained the N-Gain test results for the experimental class after the use of the Thematic Student Worksheet based on Project Based Learning, the average value of competency achievement has increased amounting to 13.16765 . The average N-Gain value is 0.451418 shows that the increase in the average value of the achievement of competence of students included in the medium category. Whereas in the control class the average value of competency achievement has increased as big as 1.5588. The average $\mathrm{N}$-Gain value is equal to 0.304851 shows that the increase in the average value of competency achievement is included in the medium category.

Based on the calculation of the results of the N-Gain analysis above, it can be concluded that the increase in the average achievement of competency and the N-Gain value of the experimental class is higher than the control class. This shows that Thematic Student Worksheet based on Project Based Learning are able to improve student learning outcomes better than conventional learning media.

The results of the study are in accordance with the results of research Ozmen \& Yildirim (2011: 4) that Student Worksheet more effective than classes taught by conventional methods. Because students actively participate in learning and teachers can determine learning targets that can be achieved or changes in behavior that can be expressed and mental attitudes that can be formed through learning.

\subsection{Limitations of Developing Student Worksheets Based on Problem Based Learning}

Product development results in Thematic Student Worksheet based on Project Based Learning certainly have some limitations, that is:

Researchers only take the results of research in the form of cognitive learning outcomes and do not process affective and psychomotor learning outcomes to be used as indicators of learning success. This is because 
changing the attitude of students into good students takes a long time while researchers have limited time, energy, and cost. The material developed in the Project-Based Learning Thematic Student Worksheets is only on one competency, that is the material.Difficulty finding relationships between subjects with one another. So the product Thematic Student Worksheets based on Project Based Learning can be developed at any time in accordance with curriculum development.

\section{CONCLUSION}

Based on the results of research on the development of Student Worksheets based on project-based learning for fifth grade at Public Elementary School 1 Margakaya, South Lampung Regency, it can be concluded as follows.

4.1 Student Worksheets Model based on Based Project Based Learning to improve learning outcomes of fifthgrade students in Elementary School which has been developed based on the design expert's judgment and the material is declared valid by the expert.

4.2 Student Worksheet Model Based on Project Based Learning is effective for improving learning outcomes of fifth-grade students in Elementary School which has been developed is used as one of the media in the thematic learning process.

\section{SUGGESTIONS}

Development of Student Worksheets based on Problem Based Learning requires educators who are creative in presenting material, possessing abilities and skills, actively engaging students according to low, medium, and high absorbency.

\section{REFERENCES}

Abidin, Yunus. 2014. Desain Sistem Pembelajaran Dalam Konteks Kurikulum 2013. PT. Refika Aditama. Bandung

Borg, W. R. \& Gall, M. D. (1983). Educational research: an introduction (4thed). New York \& London: Longman Inc.Departemen Pendidikan dan Kebudayaan. (2013). Peraturan Menteri Pendidikan dan Kebudayaan No 65 Tahun 2013 tentang Standar Proses.

Dirman dan Cicih Juarsih. (2014). Teori Belajar dan Prinsip-prinsp Pembelajaran yang mendidik. Jakarta: PT. Rineka Cipta

Hosnan, M. 2014. Pendekatan Saintifik dan Kontekstual dalam Pembelajaran Abad 21. Ghalia Indonesia . Bogor. Al-Attas, Syed Muhammad Naquib. A Commentary on the Hujjat Al-Siddiq of Nur Al-Din Al-Raniri. Kuala Lumpur: Ministry of Education and Culture, 1986.

Ozman \& Yildrim. 2011. Effect of Worksheets on Student's Succes Acid and Based Sampel. Journal of Turkish Education. 2 (2) : 10-13

Sukmadinata, S. N. (2012). Metode penelitian pendidikan. Bandung: PT Remaja Rosdakarya.

Sutama. 2012. Metode Penelitian Pendidikan. Fairuz Media. Surakarta

Sundayana. 2015. Statistika Penelitian Pendidikan. Bandung: Alfabeta.

Watson, P. 2002. The role and integration of learning outcomes into the

Widjajanti, Endang. 2008. Pelatihan Penyusunan LKS Mata Pelajaran Kimia Berdasarkan Kurikulum Tingkat Satuan Pendidikan. UNY.Jogjakarta 